\title{
Composition, distribution and diversity of tree species under different management systems in the hill forests of Bharse Village, Gulmi District, Western Nepal
}

\author{
Chinta Mani Gautam* and Teiji Watanabe \\ Laboratory of Geoecology, Graduate School of Environmental Earth Science, Hokkaido University, Sapporo, Hokkaido, JAPAN \\ *To whom corresponds should be addressed.E-mail: gautam207@yahoo.com
}

\begin{abstract}
Species composition, distribution and diversity of tree species were compared in three forest stands in the Bharse area, Gulmi District, Nepal. These forests have distinct management systems and are used for different purposes: Raiker (RK) for controlled-cutting, Raniban (RB) for cattle grazing, and Thaple (TL) for both cutting and cattle grazing. The total density of trees in RK was higher ( $2640 \mathrm{ha}^{-1}$ ) than that in RB $\left(2533 \mathrm{ha}^{-1}\right)$ and TL $\left(1875 \mathrm{ha}^{-1}\right)$. However, the largest basal area $\left(105 \mathrm{~m}^{2} \mathrm{ha}^{-1}\right)$ was found in RB while RK and TL were calculated at $72 \mathrm{~m}^{2} \mathrm{ha}^{-1}$ and $58 \mathrm{~m}^{2} \mathrm{ha} \mathrm{a}^{-1}$, respectively. The distribution of species showed clump behavior in the grazing forests whereas mixed (clump and regular) distribution occurred in the controlled-cutting forest. Trees with small diameter size were more in the controlled-cutting forest (RK) than the forests used for grazing and/or cutting (RB and TL). Species richness was highest in forest opened for cattle grazing. However, values of tree species diversity and evenness were higher in the controlled-cutting forest than in the forests with grazing and/ or cutting. One might conclude that controlled cutting is more effective than grazing and/or cutting in conserving the diversity of tree species.
\end{abstract}

Key words: Trees, distribution, composition, diversity, management system, hill forest, Nepal

Himalayan J ournal of Sciences 3(5): 67-74, 2005

Available online at: www.himjsci.com
Received: 20 Aug 2004

Accepted after revision: 27 April 2005
Copyright@ 2005 by Himalayan Association for the Advancement of Science (HimAAS)
The structure of tree species diversity in hill forests varies greatly from place to place due to variation of altitude, orientation of slope, nature of soil, and type and intensity of disturbance (Stainton 1972, Vetaas 2000). Natural disturbances such as forest fire, landslide, volcanic activity, and climatic change, determine forest dynamics and tree diversity (Burslem and Whitmore 1999, Masaki et al. 1999). They can also affect tree population and can modify interactions among species in plant communities (Connell 1978, Huston 1994). Similarly, anthropogenic disturbance may regulate the regeneration dynamics, structure and floristic composition of forest (Ewel et al. 1981, Hong et al. 1995). The effect of anthropogenic disturbance on forests may be either positive or negative, depending on the intensity of the disturbance. However, the disturbance intensity may differ from place to place among the existing forests in a particular area. Disturbance may increase species richness in old growth forest (Sheil 1999) and may maintain species diversity (Huston 1979, Petraitis et al. 1989). Frequent and low intensity disturbance (for example, grazing, or extraction of firewood and fodder) strongly affects forest structure and the succession of tree species in the forest (Ramirez-Marcial et al. 2001). However, such factors do not necessarily hamper a genuine old-growth forest (Phillips et al. 1997). Therefore, any generalization about the effect of anthropogenic disturbance on forest needs further research and discussion.

Species composition of forests has been documented for Nepal over several decades (Hara 1966, Shrestha 1982). Anthropogenic disturbances in the form of deforestation for diverse purposes (collection of timber and firewood, expansion of agriculture land and human settlement) have been a serious issue for sustainable development since the 1970s (World Bank 1978, Bishop 1990). Most previous studies have focused on the socio-economic and environmental impact of decline in forest cover. The ecological changes associated with human-induced disturbance of forests in the hill forests of Nepal have, however, received relatively little attention (Khatry-Chhetry 1997, Acharya 1999). This study analyzes the impact of humaninduced disturbance under three different forest management systems in terms of species composition, distribution pattern, and diversity.

\section{Study area}

Within the Bharse area (1400-2572 masl), we selected three forest stands: Raiker, Raniban, and Thaple (hereafter RK, $\mathrm{RB}$, and TL, respectively) (Table 1). The forest cover in this area has remained virtually unchanged since the 1960s, though the disturbance intensity among the forest stands has varied (Gautam and Watanabe 2004a). A low degree of disturbance characterizes RK whereas the RB and TL have been known to moderate and high levels of disturbances, respectively.

We surveyed 55 plots, each covering $50 \mathrm{~m}^{2}$. These forest patches lie on the southern slope of the Satyabati Range. The highest summit of this mountain ridge attains 2572 masl, and the area is characterized by steep slopes $\left(>30^{\circ}\right)$. Annual rainfall is $2500-3000 \mathrm{~mm}$. Snowfall occasionally occurs during winter seasons on the top of the Satyabati Range. The predominant forest tree species are Quercus species at higher altitude and Schima-Castanopsis species at lower. 
The forests selected for this study have been managed by local people since 1952 (Budhathoki 1955, Gautam 2005). RK has been used only for timber cutting, for which the management committee collects a fee. RB is open for cattle grazing but the collection of forest products of any kind is prohibited. In some places, however, evidence of tree-cutting (stumps) and lopping was observed. TL is used for both cutting (fodder, firewood and timber) and cattle grazing. Therefore, TL, though located farther from settlements, has more intense disturbance than RK and RB.

\section{Methodology}

The number of sampled plots varies according to the size and shape of the forests. The circular plot with radius of $3.99 \mathrm{~m}$ was designed with slope correction in the mountainous area. Circular plot was preferred over rectangular one, for it is convenient to construct. The spacing between the plots in a given forest patch was about $200 \mathrm{~m}$. In each plot, we measured floristic composition (total number of woody species), stand structure (species type and density), and dbh at $1.3 \mathrm{~m}$ height for trees with diameter greater than $5 \mathrm{~cm}$. The measurements were conducted in Nov-Dec 2002 and Mar-Apr 2003.

We calculated relative values of density, frequency, and dominance in order to find the importance value index (IVI) and the important percentage (IMP) for each species according to Mueller-Dombois and Ellenberg (1974). We broke down dbh into ten classes of diameter size (in centimeters): 5-10, 10-15, $15-20,20-25,25-30,30-35,35-40,40-45,45-50$, and $\geq 50$; then we determined the stocking density of each size class. We calculated expected values for each diameter class using a negative exponential model following de Liocourt (1898) (Eq 1), in order to determine the impact of human disturbance on each diameter class of trees. We analyzed distribution of species using variance to mean ratio (Ludwig and Reynolds 1988) at the forest level.

$$
\mathrm{aq}^{\mathrm{n}-1} \mathrm{aq}^{\mathrm{n}-2} \quad \mathrm{aq}^{\mathrm{n}-3} \mathrm{aq}^{\mathrm{n}-4} \ldots \ldots . . \mathrm{aq}^{3} \quad \mathrm{aq}^{2} \quad \mathrm{aq}^{1} \mathrm{a}
$$

where,

a, number of trees in the largest size class of interest

$\mathrm{q}$, ratio between diameter class

n, number of classes (de Liocourt 1898)

We calculated species richness or number of species per unit area (Shannon and Weiner 1949, Margalef 1958); species diversity index (Simpson 1949); and evenness, or distribution of abundances among the species (Shannon andWeiner 1949) following Eq2, Eq 3, Eq 4, and Eq 5.

Species richness

a. Margalef index

$$
S R=\frac{S-1}{\ln (n)}
$$

b. Shannon-Weiner index

$$
H^{\prime}=-\sum_{i=1}^{s} p_{i} \ln p_{i}
$$

Simpson's diversity

$$
D=1-\lambda \quad\left(\lambda=\sum_{i=1}^{s} p_{i}^{2}\right)
$$

Evenness

$$
E=\frac{H^{\prime}}{\ln (S)}
$$

where,

$S$, number of species

ln, natural logarithm

$n$, total number of individual trees in the area

$\lambda$, Simpson's concentration of dominance

$p_{i}$, the proportion of individuals found in the $\mathrm{i}_{\text {th }}$ species

\section{Results}

Forests of the Bharse area are considered indigenously managed forests except for some privately owned patches, even though in the legal sense they are all under the national forest owned by the government. The forest management system in the Bharse area was formally initiated in 1952 by communities within theVDC in order to protect forest resources and reduce the risk of landslide, drought and scarcity of water (Budhathoki, 1955). At first there were six banpales (forest guards) under the forest management committee, including eleven members of the Village Panchayat. Since 1995 there have been only two banpales to manage the entire forested area of Bharse. Every household contributes to the protection of forest resources by respecting the regulations they themselves drew up. As a result, the forest area has increased (Gautam and Watanabe 2004a).

A total of 652 trees representing 32 species were identified within the sampled areas in three forest stands: 198 trees (15 species) in RK, 304 trees (22 species) in RB, and 150 trees (11 species) in TL. The largest number of trees, $2640 \mathrm{ha}^{-1}$, was found in forest RK (Table 2) whereas the greatest basal area, 105.19 $\mathrm{m}^{2} \cdot \mathrm{ha}^{-1}$, was found in RB (Table 3). Both the number of trees $\left(1875 \mathrm{ha}^{-1}\right)$ and the basal area $\left(58.35 \mathrm{~m}^{2} \cdot \mathrm{ha}^{-1}\right)$ were smallest in TL (Table 4).

\section{Species-area curve}

A species-area curve for natural forest indicates the quick addition of newer species in consecutive plots at first, followed by stabilization (Shankar et al. 1998). In our study, the rate of species addition increased gradually up to the 4 th plot and was constant from the 4 th to 6 th plot in all forests (Figure 1). In RB

TABLE 1. General characteristics of the studied forests

\begin{tabular}{llll}
\hline & RK & RB & TL \\
\hline Area $\left(\mathrm{km}^{2}\right)$ & 1.12 & 2.04 & 0.83 \\
\hline Sample plots & 15 & 24 & 16 \\
\hline Slope aspect & $\mathrm{S}, \mathrm{SE}$ & $\mathrm{S}, \mathrm{SW}, \mathrm{SE}$ & $\mathrm{S}, \mathrm{SW}$ \\
\hline Altitude $(\mathrm{m})$ & $1480-2100$ & $1620-2390$ & $1850-2570$ \\
\hline Slope gradient & \multicolumn{2}{c}{$>30^{\circ}$} \\
\hline $\begin{array}{l}\text { Distance by foot from } \\
\text { settlementin minutes }\end{array}$ & $10-60$ & $5-55$ & $70-120$
\end{tabular}

\begin{tabular}{llll}
\hline Soil type/texture* & \multicolumn{3}{c}{ Lithic subgroups of ustorthents /loamy skeletal } \\
\hline & Controlled-cutting & Managed, but & Open: no \\
& only for timber & open for & restriction on either \\
Management status** & paying a fee to & unrestricted & cattle grazing or \\
& management & grazing & collection of forest \\
& committee & & products \\
\hline
\end{tabular}

RK: Raiker; RB: Raniban; TL: Thaple; *LRMP (1986); **Field survey in 2002 
TABLE 2. Statistical summary of tree species of the forest in Raiker (RK)

\begin{tabular}{|c|c|c|c|c|c|c|c|c|c|}
\hline Species & Code & $\begin{array}{c}D \\
\left(h a^{-1}\right)\end{array}$ & $\begin{array}{c}\mathbf{F} \\
\left(h a^{-1}\right)\end{array}$ & $\begin{array}{c}\text { BA } \\
\left(m^{2} \cdot h a^{-1}\right)\end{array}$ & $\mathrm{RD}$ & RF & RDM & MI & IMP \\
\hline Schima wallichii (D.C.) Korth. & S32 & 627 & 187 & 20.23 & 23.74 & 16.67 & 28.06 & 68.46 & 22.82 \\
\hline Quercus lanata Roxb. & S28 & 387 & 147 & 19.25 & 14.65 & 13.10 & 26.69 & 54.43 & 18.14 \\
\hline Rhododendron arboreum Smith & S31 & 440 & 160 & 9.37 & 16.67 & 14.29 & 13.00 & 43.95 & 14.65 \\
\hline Quercus semecarpifolia Sm. & $S 29$ & 227 & 80 & 9.98 & 8.59 & 7.14 & 13.85 & 29.57 & 9.86 \\
\hline Castanopsis indica (Roxb.) A.DC. & $\mathrm{S} 02$ & 213 & 93 & 5.44 & 8.08 & 8.33 & 7.55 & 23.96 & 7.99 \\
\hline Luculia gratissima (Wall.) Sweet. & S16 & 227 & 93 & 1.72 & 8.59 & 8.33 & 2.38 & 19.30 & 6.43 \\
\hline Myrica esculenta Buch-Hom. ex D. Don & S20 & 93 & 80 & 1.67 & 3.54 & 7.14 & 2.32 & 13.00 & 4.33 \\
\hline Lauri layanch* & $\mathrm{S} 12$ & 93 & 80 & 0.51 & 3.54 & 7.14 & 0.71 & 11.39 & 3.80 \\
\hline Pinus roxburghii Sargent & S24 & 107 & 53 & 0.84 & 4.04 & 4.76 & 1.17 & 9.97 & 3.32 \\
\hline Myrsine semiserrata Wall. & $\mathrm{S} 21$ & 67 & 27 & 1.65 & 2.53 & 2.38 & 2.28 & 7.19 & 2.40 \\
\hline Osmanthus fragrans (DC.) H.Hara. & S22 & 53 & 40 & 0.55 & 2.02 & 3.57 & 0.77 & 6.36 & 2.12 \\
\hline Fraxinus floribunda Wall. & S07 & 53 & 40 & 0.30 & 2.02 & 3.57 & 0.42 & 6.01 & 2.00 \\
\hline Machilus odoratissima Nees & S18 & 27 & 13 & 0.16 & 1.01 & 1.19 & 0.23 & 2.43 & 0.81 \\
\hline Castanopsis tribuloides (Smith) A. DC. & S03 & 13 & 13 & 0.38 & 0.51 & 1.19 & 0.53 & 2.23 & 0.74 \\
\hline Eriobotrya dubiya (Lindl.) Dence. & S04 & 13 & 13 & 0.04 & 0.51 & 1.19 & 0.06 & 1.75 & 0.58 \\
\hline Total $(n=15)$ & & 2640 & 1120 & 72.12 & 100.00 & 100.00 & 100.00 & 300.00 & 100.00 \\
\hline
\end{tabular}

D: density; F: frequency; BA: basal area; RD: relative density; RF: relative frequency; RDM: relative dominance; IVI: importance value index; IMP: important percentage; *: local name

TABLE 3. Statistical summary of tree species of the forest in Raniban (RB)

\begin{tabular}{|c|c|c|c|c|c|c|c|c|c|}
\hline Species & Code & $\mathrm{D}\left(\mathrm{ha}^{-1}\right)$ & $F\left(h^{-1}\right)$ & $\begin{array}{c}\text { BA } \\
\left(\mathrm{m}^{2} \cdot h \mathrm{a}^{-1}\right)\end{array}$ & $\mathrm{RD}$ & RF & RDM & IM & IMP \\
\hline Quercus semecarpifolia Sm. & S29 & 800 & 133 & 29.68 & 31.58 & 15.38 & 28.21 & 75.18 & 25.06 \\
\hline Quercus lanata Roxb. & S28 & 175 & 83 & 28.19 & 6.91 & 9.62 & 26.80 & 43.32 & 14.44 \\
\hline Lyonia ovalifolia (Wall.) Drude & S17 & 358 & 100 & 9.52 & 14.14 & 11.54 & 9.05 & 34.73 & 11.58 \\
\hline Schima wallichii (D.C.) Korth. & $\mathrm{S} 32$ & 250 & 67 & 16.03 & 9.87 & 7.69 & 15.24 & 32.80 & 10.93 \\
\hline Rhododendron arboreum Smith & S31 & 158 & 58 & 3.97 & 6.25 & 6.73 & 3.77 & 16.75 & 5.58 \\
\hline Castanopsis tribuloides (Smith) A. DC. & S03 & 125 & 58 & 3.60 & 4.93 & 6.73 & 3.43 & 15.09 & 5.03 \\
\hline Eurya cerasifolia (D. Don.) Kobuski & S05 & 125 & 67 & 1.70 & 4.93 & 7.69 & 1.61 & 14.24 & 4.75 \\
\hline Castanopsis indica (Roxb.) A. DC. & S02 & 125 & 58 & 1.98 & 4.93 & 6.73 & 1.88 & 13.55 & 4.52 \\
\hline Prunus cerasoides D. Don & S26 & 58 & 33 & 1.82 & 2.30 & 3.85 & 1.73 & 7.88 & 2.63 \\
\hline Machilus odoratissima Nees & S18 & 67 & 25 & 0.85 & 2.63 & 2.88 & 0.80 & 6.32 & 2.11 \\
\hline Myrica esculenta Buch.-Ham. ex D. Don & $\mathrm{S} 20$ & 42 & 25 & 1.84 & 1.64 & 2.88 & 1.75 & 6.28 & 2.09 \\
\hline Alnus nepalensis D. Don & S01 & 67 & 17 & 1.31 & 2.63 & 1.92 & 1.25 & 5.80 & 1.93 \\
\hline Ficus nemorelis Wall & S06 & 33 & 25 & 0.63 & 1.32 & 2.88 & 0.60 & 4.80 & 1.60 \\
\hline Grewia species & S09 & 33 & 25 & 0.40 & 1.32 & 2.88 & 0.38 & 4.58 & 1.53 \\
\hline Eriobotrya dubiya (Lindl.) Dence. & S04 & 25 & 25 & 0.59 & 0.99 & 2.88 & 0.56 & 4.43 & 1.48 \\
\hline Quercus spicata Smith & S30 & 25 & 17 & 0.41 & 0.99 & 1.92 & 0.39 & 3.30 & 1.10 \\
\hline Litsea doshina Buch.- Ham.ex D.Don & S15 & 17 & 8 & 1.14 & 0.66 & 0.96 & 1.08 & 2.70 & 0.90 \\
\hline Garuga pinnata Roxb. & S08 & 17 & 8 & 0.29 & 0.66 & 0.96 & 0.28 & 1.90 & 0.63 \\
\hline Michelia champaca L. & S19 & 8 & 8 & 0.64 & 0.33 & 0.96 & 0.61 & 1.90 & 0.63 \\
\hline Myrsine semiserrata Wall. & S21 & 8 & 8 & 0.25 & 0.33 & 0.96 & 0.24 & 1.53 & 0.51 \\
\hline Pyrus pashia Buch.-Ham. ex D. Don & S27 & 8 & 8 & 0.19 & 0.33 & 0.96 & 0.18 & 1.47 & 0.49 \\
\hline Ghan Ghane* & $\mathrm{S} 10$ & 8 & 8 & 0.17 & 0.33 & 0.96 & 0.16 & 1.45 & 0.48 \\
\hline Total $(n=22)$ & & 2533 & 867 & 105.19 & 100.00 & 100.00 & 100.00 & 300.00 & 100.00 \\
\hline
\end{tabular}

D: density; F: frequency; BA: basal area; RD: relative density; RF: relative frequency; RDM: relative dominance; IVI: importance value index;

IMP: important percentage; *: local name 
TABLE 4. Statistical summary of tree species of the forest in Thaple (TL)

\begin{tabular}{|c|c|c|c|c|c|c|c|c|c|}
\hline Species & Code & $D\left(h a^{-1}\right)$ & $F\left(h a^{-1}\right)$ & $\begin{array}{r}\text { BA } \\
\left(m^{2} \cdot h a^{-1}\right)\end{array}$ & RD & RF & RDM & IM & IMP \\
\hline Quercus semecarpifolia Sm. & S29 & 675 & 150 & 12.45 & 36.00 & 23.53 & 21.34 & 80.87 & 26.96 \\
\hline Rhododendron arboreum Smith & S31 & 213 & 100 & 9.68 & 11.33 & 15.69 & 16.59 & 43.61 & 14.54 \\
\hline Eurya cerasifolia (D. Don.) Kobuski & S05 & 200 & 75 & 8.62 & 10.67 & 11.76 & 14.78 & 37.21 & 12.40 \\
\hline Lindera species (Shere*) & S14 & 200 & 63 & 6.69 & 10.67 & 9.80 & 11.47 & 31.94 & 10.65 \\
\hline Garuga pinnata Roxb. & 508 & 200 & 75 & 2.79 & 10.67 & 11.76 & 4.78 & 27.21 & 9.07 \\
\hline Lyonia ovalifolia (Wall.) Drude & S17 & 200 & 50 & 2.65 & 10.67 & 7.84 & 4.54 & 23.05 & 7.68 \\
\hline Patale* & S23 & 75 & 38 & 6.04 & 4.00 & 5.88 & 10.35 & 20.23 & 6.74 \\
\hline Myrsine species (Bajra Danthhi*) & $\mathrm{S} 25$ & 25 & 25 & 6.44 & 1.33 & 3.92 & 11.05 & 16.30 & 5.43 \\
\hline Ilex insignis Hook. F. & $\mathrm{S} 11$ & 63 & 38 & 2.82 & 3.33 & 5.88 & 4.84 & 14.05 & 4.68 \\
\hline Ghan Ghane* & $\mathrm{S} 10$ & 13 & 13 & 0.13 & 0.67 & 1.96 & 0.22 & 2.85 & 0.95 \\
\hline Lindera species (Goal Saple*) & S13 & 13 & 13 & 0.03 & 0.67 & 1.96 & 0.04 & 2.67 & 0.89 \\
\hline Total $(n=11)$ & & 1875 & 638 & 58.35 & 100.00 & 100.00 & 100.00 & 300.00 & 100.00 \\
\hline
\end{tabular}

D: density; F: frequency; BA: basal area; RD: relative density; RF: relative frequency; RDM: relative dominance; IVI: importance value index; IMP: important percentage; $*$ local name

TABLE 5. Distribution pattern of dominant and co-dominant species

\begin{tabular}{lccc}
\hline \multirow{2}{*}{ Species } & \multicolumn{3}{c}{ Distribution pattern in } \\
\cline { 2 - 4 } & Raiker (RK) & Raniban (RB) & Thaple (TL) \\
\hline Castanopsis tribuloides & $\mathrm{R}$ & $\mathrm{C}$ & - \\
\hline Castanopsis indica & $\mathrm{C}$ & $\mathrm{C}$ & - \\
\hline Eurya cerasifolia & - & $\mathrm{C}$ & $\mathrm{C}$ \\
\hline Garuga pinnata & - & $\mathrm{C}$ & $\mathrm{C}$ \\
\hline Lindera species (Shere*) & - & - & $\mathrm{C}$ \\
\hline Luculia gratissima & $\mathrm{C}$ & - & - \\
\hline Lyonia ovalifolia & - & $\mathrm{C}$ & $\mathrm{C}$ \\
\hline Patale* & - & - & $\mathrm{C}$ \\
\hline Myrsine species & - & - & $\mathrm{R}$ \\
\hline Quercus semecarpifolia & $\mathrm{C}$ & $\mathrm{C}$ & $\mathrm{C}$ \\
\hline Quercus lanata & $\mathrm{R}$ & $\mathrm{C}$ & - \\
\hline Rhododendron arboreum & $\mathrm{C}$ & $\mathrm{C}$ & $\mathrm{C}$ \\
\hline Schima wallichii & $\mathrm{R}$ & $\mathrm{C}$ & - \\
\hline
\end{tabular}

*: local name; R: regular; C: clumped; -: absence

the curve leveled off between the 7th and the 19th plot and then increased slightly up to the 21st plot. The curve leveled off completely after the 21st plot. In RK, the curve leveled off after the 10th plot, whereas in TL it leveled off after the 11th plot. The curve of all forests shows that the sample plots are sufficient for these specific forests. The species-area curve for TL shows that the number of species is small compared to other forests (Figure 1). Grazing and cutting led to the poor number of species.

\section{Species composition}

The importance percentage (IMP) shows that Schima wallichii is a dominant species of forest RK (Table 2). The co-dominant
TABLE 6. Density-diameter distribution

\begin{tabular}{cllllll}
\hline \multirow{2}{*}{ Diameter } & \multicolumn{3}{c}{ Raikar (RK) } & \multicolumn{2}{c}{ Raniban (RB) } & \multicolumn{2}{c}{ Thaple (TL) } \\
\cline { 2 - 7 } & OD & ED & OD & ED & OD & ED \\
\hline $5-10$ & 1013.3 & 1255.9 & 425.0 & 1198.6 & 512.5 & 883.3 \\
\hline $10-15$ & 426.7 & 775.9 & 591.7 & 842.1 & 450.0 & 594.4 \\
\hline $15-20$ & 480.0 & 479.4 & 591.7 & 591.7 & 400.0 & 400.0 \\
\hline $20-25$ & 186.7 & 296.2 & 316.7 & 415.7 & 212.5 & 269.2 \\
\hline $25-30$ & 240.0 & 183.0 & 275.0 & 292.1 & 112.5 & 181.1 \\
\hline $30-35$ & 160.0 & 113.1 & 141.7 & 205.2 & 25.0 & 121.9 \\
\hline $35-40$ & 93.3 & 69.9 & 108.3 & 144.2 & 75.0 & 82.0 \\
\hline $40-45$ & 13.3 & 43.2 & 33.3 & 101.3 & 62.5 & 55.2 \\
\hline $45-50$ & 26.7 & 26.7 & 33.3 & 71.2 & 0.0 & 37.1 \\
\hline$>50$ & - & - & 50.0 & 50.0 & 25.0 & 25.0 \\
\hline Ratio (q) & 1.62 & \multicolumn{7}{c}{1.42} & \\
\hline
\end{tabular}

OD: observed density; ED: expected density; -: absence

Ratio (q) was calculated using negative exponential model (de Liocourt 1898) (Eq 1)

TABLE 7. Diversity indices of the studied forests

\begin{tabular}{l|l|c|c|r}
\hline \multicolumn{2}{l|}{ Diversity indices } & RK & RB & TL \\
\hline \multirow{2}{*}{$\begin{array}{l}\text { Species } \\
\text { richness }\end{array}$} & Margalef & 2.64 & 3.67 & 1.99 \\
\cline { 2 - 5 } & Shannon-Wiener's index & 2.26 & 2.36 & 1.93 \\
\hline Simpson's index & 0.87 & 0.85 & 0.81 \\
\hline Evenness (Shannon-Weiner) & 0.83 & 0.76 & 0.81 \\
\hline
\end{tabular}

species of RKare Quercus lanata and Rhododendron arboreum. Quercus semecarpifolia is the dominant species of RB and TL (Tables 3 and 4). The co-dominant species of these forests 


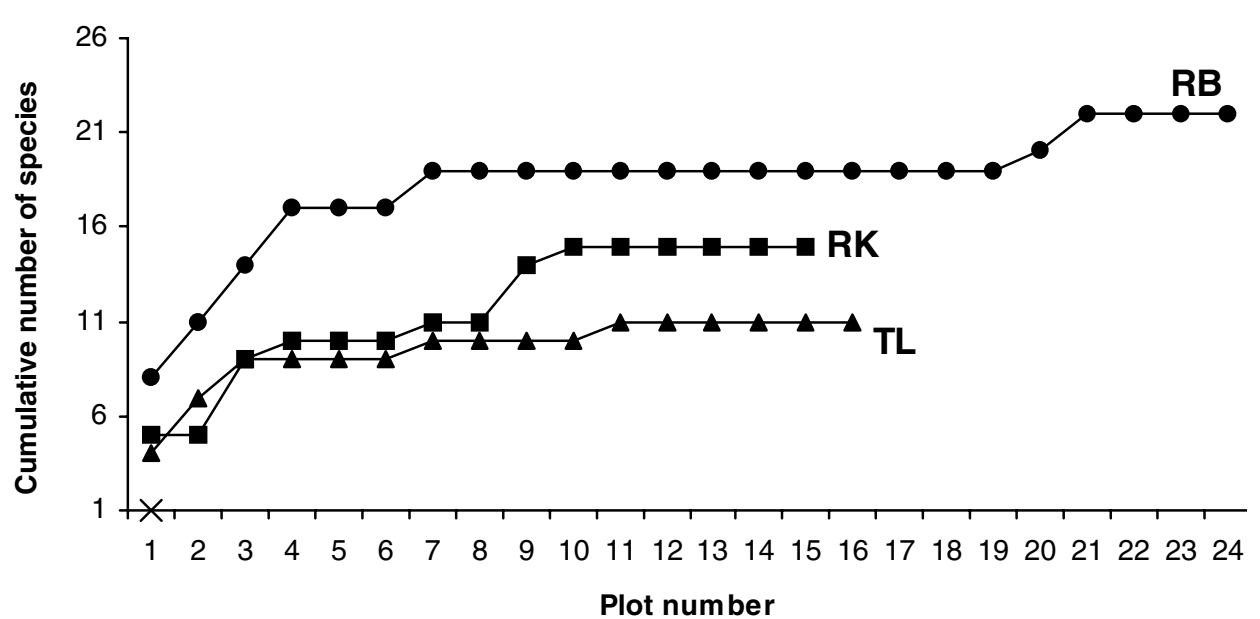

FIGURE 1. Species-area curves for forests RK, RB and TL

distribution among all forests (Table 5). In forests open to cattle grazing $(\mathrm{RB})$ and cattle grazing plus cutting (TL), all species showed a clumped distribution, with the exception of Myrsine species in forest TL. Castanopsis tribuloides, Quercus lanata, and Schima wallichii were found to have regular distribution in forest managed for cutting (RK); but a clumped distribution in RB. No uniform distribution occurred among the forests studied.

Density-diameter distribution

There were large differences among forests in the densities of each dbh size class (Table 6). The theoretical distribution of density-

are quite different: Rhododendron arboreum, Eurya ceracifolia and Lindera species (Shere in local name) in TL, Quercus lanata, Lyonia ovalifolia and Schima wallichii in RB.

The tree species composition of all surveyed forests is given in Figure 2. Some species were found only in one particular forest (Figure 2). However, two species (S29 and S31) were found to be common in all three forests. Eight species (S02, S03, S04, S18, S20, S21, S28 and S32) were found to be common to RK and RB, whereas four species (S05, S08, S10 and S17) were common to RB and TL. Forests RK and TL do not have species in common except the two most prevalent species, S29 and S31. In summary, RK and TL have different characteristics in their species composition, whereas RB has many species in common with both RK and TL (Figure 2).

\section{Species distribution}

Two species, Quercus semecarpifolia and Rhododendron arboreum, were consistently found to be in clumped

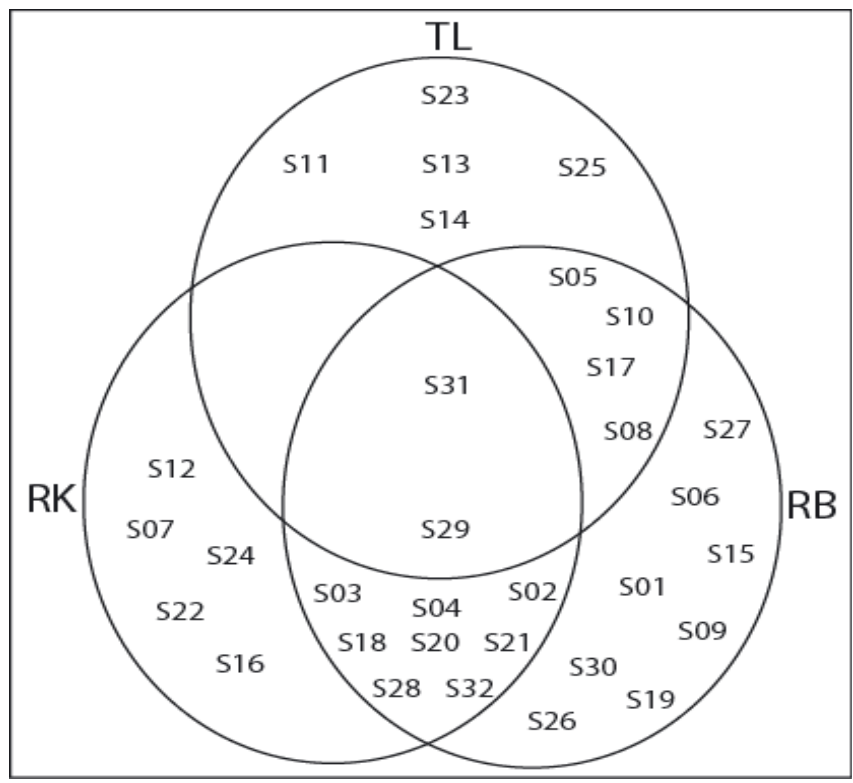

FIGURE 2. Species composition in the studied forests. S01...S32 are species symbols (see Tables 2-4)

diameter in an uneven-aged forest should roughly approximate a reverse J (Kairo et al. 2002). But in the studied forests the density-diameter curve showed a multimodel distribution quite different from the typical reverse J (Figure 3). In each of our stands, the density of the 15-20 cm diameter class was higher than those of the preceding and successive size classes. We surmised, therefore, that $15-20 \mathrm{~cm}$ was the undisturbed class for all forests. We then calculated the ratio between the actual densities of diameter classes and the expected values, using de Liocourt's negative exponential model.

For the 10-15, 20-25 and 40-45 cm dbh classes, the tree density is low in RK compared to the density of preceding and successive dbh classes (Figure 3a). No trees were found with diameter size greater than $45 \mathrm{~cm}$ in RK. However, the observed density of the 25-30 and 30-35 cm dbh classes was slightly higher than the expected density.

In contrast, the density of $5-10 \mathrm{~cm}$ dbh trees was very low in RB compared to the 10-15 cm dbh class (Figure $3 \mathbf{b}$ ). Small differences were found between observed and expected tree densities in the 10-15, 20-25 and 40-45 cm dbh classes. The density of smaller size trees was low in RB due to grazing.

The total number of trees was quite low in TL, and, due to grazing and cutting, there were quite few of small trees (Figure 3c). The observed density of the $30-35$ and $45-50 \mathrm{~cm}$ dbh classes was smaller than their preceding and successive dbh size classes.

\section{Diversity indices}

Species richness of Margalef ranged from 1.99 to 3.67, with RB having the highest value and TL the lowest (Table 7). Similar pattern was observed by Shannon-Weiner index. However, RK had the highest values for Simpson's index (0.87) and evenness (0.83).

\section{Discussion}

TL, distant from the settlements of Dabhung and Bharse, showed signs of more intense disturbance than RK and RB, which are located near the above settlements. Our research shows that this difference is due to the fact that a wide variety of resources are legally harvested from TL (Table 1). This finding contradicts the general consensus that forests close to settlements are invariably more intensively exploited than more remote forests (e.g., Acharya 1999, Sagar et al. 2003). 
Analysis of tree species composition in the three forests showed different assemblages with different dominants and co-dominants. However, there were some similarities (Figure 2). The two major species in the study area, Quercus semecarpifolia and Rhododendron arboreum, were found in all three sites. The main differences in the species composition may be due to altitudinal gradient (Table 1), a feature not addressed in this study.

Clumped distribution is common in undisturbed forests, while regular distribution is generally found only in very uniform environments (Odum 1971). Species distribution in our study sites tended to be clumped, except for Myrsine species, in those forests subject to grazing and/or uncontrolled cutting whereas more species were found to have regular distribution in those forests with controlledcutting and no grazing (Table 4). Two species, Quercus semecarpifolia and Rhododendron arboreum, showed no effect of such disturbances on dispersal behavior and were characterized by clumped distribution. The various patterns of distribution of a species in each forest might have been caused by various factors such as mode of seed dispersal (Richards 1996), gap on growth of numerous saplings (Newbery et al. 1986) as well as peculiarities of topography, slope, and soil.

Assuming that the undisturbed tree size is15$20 \mathrm{~cm} \mathrm{dbh}$ for all forests, the observed values should be similar to the values (Figure 3) predicted by de Liocourt's negative exponential model. According to this model, the ratio between the numbers of trees in neighboring diameter classes should be roughly constant for a particular forest, but actually varies from one forest to another. This prediction has been confirmed in a number of uneven-aged forests throughout the world (Clutter et al. 1983) and applies particularly well to mixed forests with continuous natural regeneration.

If we compare the observed values for the $5-10 \mathrm{~cm}$ dbh class in each forest with the expected values, we find that regeneration of trees has been more effective in the controlled-cutting forest (RK) than in either the forest opened for grazing (RB) or the forest used for both grazing and cutting (TL). The density of the $5-10 \mathrm{~cm}$ dbh class in forests $\mathrm{RB}$ and TL (Figure $\mathbf{3 b}$ and $\mathbf{3 c}$ ) indicates that $\mathbf{a}$ cattle grazing has had a direct and substantial effect on the regeneration of tree species due to trampling and over-browsing. Forest TL showed the significant differences between the expected and observed values, except for the $35-40 \mathrm{~cm}$ and $40-45 \mathrm{~cm}$ dbh classes. However, the density in each dbh is smaller than that in the other studied forests. RK showed more complex results, although only two dbh classes have notable differences between observed and expected values (Figure 3a).

The different shapes of density-diameter distribution (Figure 3) show the extent of effect of disturbances on the density of dbh classes. In a montane rain forest in Mexico, Ramirez-Marcial et al. (2001) found that stem density decreases with disturbance intensity. Our study also found that the stem density declined with increasing disturbance. Grazing damages
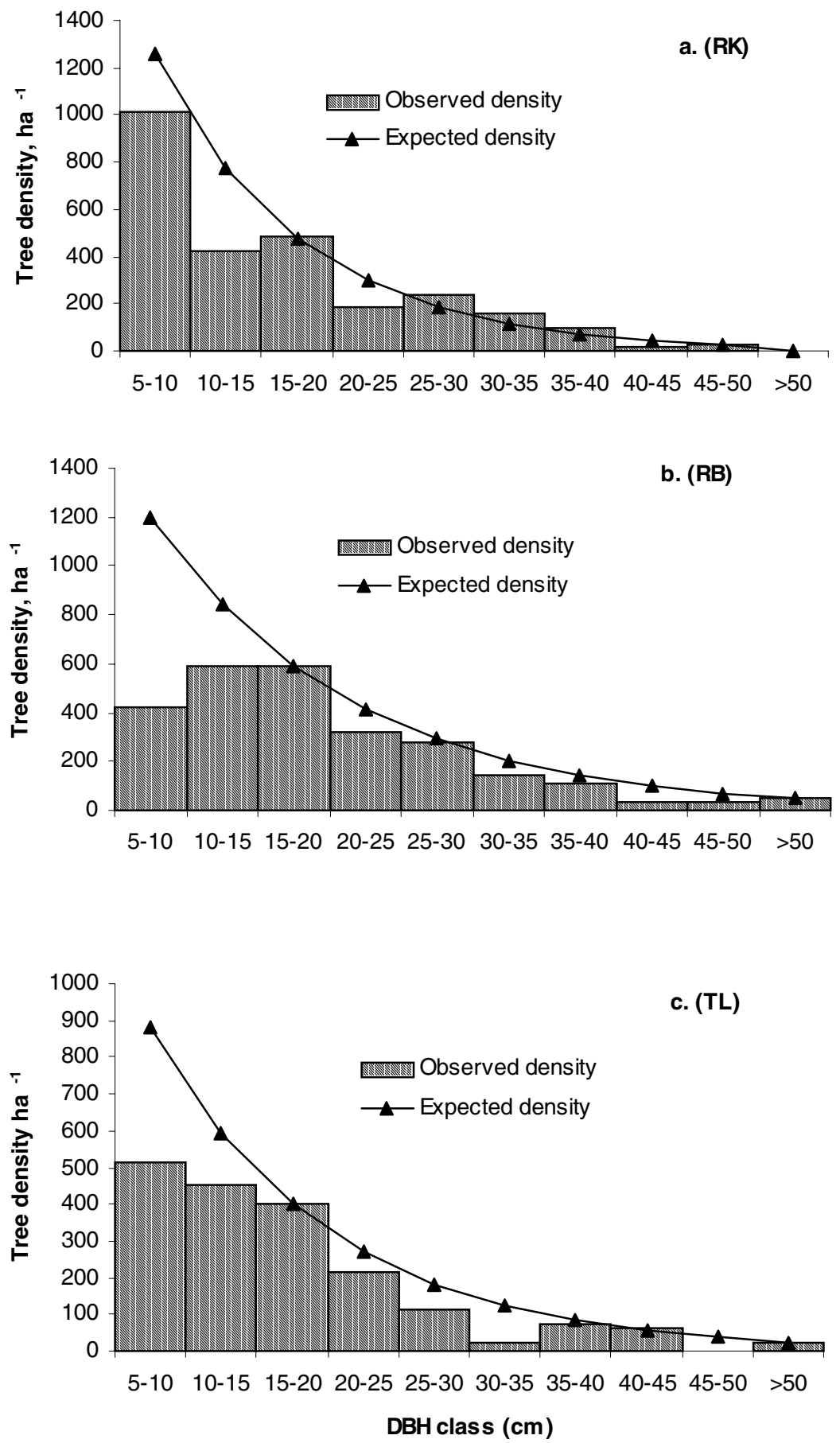

FIGURE 3. Density-diameter distribution of the studied forests

saplings through trampling and browsing (Glatzel 1999, Roder et al. 2002); therefore, the density of small diameter classes is low in the forests opened to grazing (Gautam and Watanabe, 2004a).

Both indices of species richness (Margalef and Shannon Weiner) showed higher values in forest RB than RK and TL. However, species richness value alone, though interesting, is not informative enough (Onaindia et al. 2004). Simpson's diversity index and evenness (Shannon-Weiner) showed a high value in RK (Table 7), which means that the controlled-cutting forest is in a more advanced state of regeneration compared to those forests open to grazing and/or cutting. 
Species richness was highest in $\mathrm{RB}$; however, $\mathrm{RB}$ also had the lowest value for evenness (Table 7), showing that the species are not equally abundant. This may be due to the presence of fugitive species. Only competitive species can survive in area with little or no disturbance, while fugitive species can survive in areas with high level of disturbance. Therefore, species richness is maximal at an intermediate level of disturbance (Abugov 1982). TL, a highly disturbed forest, has a medium level of evenness, which is an indication that high disturbance might have an adverse impact on evenness. However, both species richness and diversity are lowest among the studied forests because of the direct influence of disturbance. The comparison of species richness, distribution pattern, and diversity of tree species suggests that controlled-cutting is more conducive to higher diversity than either open grazing or completely open management.

The studied forests are under the national forests, controlled and managed by local people through coherent rules and regulations. Such forests are distributed throughout the entire country, and are known as an "indigenous managed forests." Generally, in Nepal, there is no consistency in defining the forest cover at the national level (HMGN 1988, HMGN 1993, DFRS 1999). It is therefore difficult to generalize how much area of forest cover is under each form of management. This study suggests that the indigenous knowledge of local people is quite sound for protecting the forest resources using various methods of management over a period of many decades. Nevertheless, studies found that many species adapted to open grazed forests can disappear (Bengtsson et al. 2002, Onaindia et al. 2004). It is likely that, in the present study, grazing resulted in a forest with more openings and gaps, leading to a higher abundance of large trees and fewer saplings. However, controlled cutting conserves the cover of those tree species typical of natural forests. Therefore, a high value of diversity can be found in those forests that have been managed for controlled-cutting. The observed value of 0.87 for Simpson's diversity in a controlled-cutting forest is higher than the average value of 0.85 reported from 104 patches of managed forests in the entire Middle Hills of Nepal (Tachibana and Adhikari 2004). It is also higher than the range of 0.70-0.82 observed in two community forests in the mid-west Nepal (Kunwar and Sharma 2004). These observations suggest that controlled cutting is the best type of management for the study area as far as the diversity of tree species is concerned.

\section{Conclusions}

An analysis of the composition, distribution (stand structure), and diversity of tree species in studied forests shows that controlled-cutting is more effective than some other management systems in conserving the diversity of tree species. However, there is no clear visible trend in the distribution of density-diameter classes. The density-diameter distribution indicates poor regeneration in forests used heavily for cattle grazing. The density was extremely low in the forest open to both cutting and grazing. However, the largest basal area was found in the grazing forest. Our data shows that the forests with grazing (RB and TL) were characterized by clumped distribution of species, whereas the forest with controlled-cutting (RK) was mixed (clumped and regular). The moderately disturbed forest, Raniban (RB), showed the highest species richness of the three forests. The differences are probably due to effective forest management practices by the local inhabitants.

\section{Acknowledgements}

We are grateful to Bahadur Ale for plant identification by local name, and Sabita Poudel, National Herbarium Center, Godawari for assistance with botanical nomenclature. Our sincere thanks go to Ram Bahadur Kala for his generous support in the field.

\section{References}

Abugov R. 1982. Species disturbance and phasing of disturbance. Ecology 63: 289-293

Acharya B. 1999. Forest bio-diversity assessment: A spatial analysis of tree species diversity of Nepal. Netherland: International Institute for Aerospace Survey and Earth Science. $199 \mathrm{p}$

Bengtsson J, SG Nilsson, A Franc and P Menozzi. 2002. Biodiversity, disturbances, ecosystem function and management of European forests. Forest Ecology and Management 132: 39-50

Bishop BC. 1990. Karnali under stress: Livelihood strategies and seasonal rhythms in a changing Nepal Himalaya. Chicago: The University of Chicago Press. $460 \mathrm{p}$

Budhathoki SP. 1955. Bharse gauko ek jhalak (in Nepali). Gulmi: Gulmi Bharse. $34 \mathrm{p}$

Burslem DFRP and TCWhitmore. 1999. Species diversity susceptibility to disturbance and tree population dynamics in tropical rain forest. Journal of Vegetation Science 10: 767-776

Clutter JL, JC Fortson, LV Pienaar, GH Brister and RL Bailey. 1983. Timber management: A quantitative approach. New York: John Wiley and Sons Inc. $352 \mathrm{p}$

Connell JH. 1978. Diversity in tropical rain forests and coral reefs. Science 199: 1302-1330

de Liocourt F 1898. De l'amenagement des sapiniers. Society of Forestry 6 : $1169-1184$

DFRS. 1999. Forest resources of Nepal (1987-1998). Kathmandu: Department of Forest Resource and Survey, HMGN and Finland: Forest Resource Information System Project, The Government of Finland. Publication no. 74

Ewel J, C Berish, B Brown, N Price and J Raich. 1981. Slash and burn impacts on a Costa Rican wet forest site. Ecology 62: 816-829

Gautam CM. 2005. Anthropogenic disturbance, floristic composition and diversity in the hill forests, Bharse area, Gulmi District of Nepal [PhD dissertation]. Sapporo (Japan): Hokkaido University. 105 p

Gautam CM and TWatanabe. 2004a. Land cover change in Himalaya with special reference to forest disturbance: a case of Bharse area, Lesser Himalaya, West Central Nepal. Himalayan Journal of Sciences 2(4): 138-139

Glatzel G. 1999. Historic forest use and its possible implication to recently accelerated tree growth in Central Europe. In: Karjalainen T, H Spieker, O Laroussine (eds), Causes and consequences of accelerated tree growth in Europe. Joensuu, Finland: European Forest Institute. p 65-74

Hara H. 1966. The flora of eastern Himalaya. Tokyo: University of Tokyo Press. $744 \mathrm{p}$

HMGN. 1988. Master plan for the forestry sector Nepal. Kathmandu: Ministry of Forest and Soil Conservation, HMGN

HMGN. 1993. Forest act 1993. Kathmandu: Ministry of Forest and Soil Conservation, HMGN

Hong SK, N Nakagoshi and M Kamada. 1995. Human impacts on pine dominated vegetation in rural landscapes in Korea and western Japan. Vegetatio 116: 161-172

Huston MA. 1979. A general hypothesis of species diversity. American Naturalist 113: 81-101

Huston MA. 1994. Biological diversity: The coexistence of species in changing landscapes. Cambridge: Cambridge University Press. $791 \mathrm{p}$

Kairo JG, F Dahdouh-Guebas, PO Gwada, C Ochieng and N Koedam. 2002. Regeneration status of mangrove forests in Mida Creek, Kenya: a compromised or secured future? Ambio 31(7): 562-568

Khatry-Chhetry DB. 1997. The ecology of warm-temperature forests in the central Himalayas across a human-induced disturbance gradient [PhD dissertation]. Michigan: Michigan University. $253 \mathrm{p}$

Kunwar RM and SP Sharma. 2004. Quantitative analysis of tree species in two community forests of Dolpa district, mid-west Nepal. Himalayan Journal of Sciences 2(3): 23-28

Ludwig JA and JF Reynolds. 1988. Statistical ecology: A primer on methods and computing. Canada: John Wiley and Sons. $368 \mathrm{p}$

Margalef R. 1958. Information theory in ecology. General Systematics 3: $36-71$

Masaki T, H Tanaka, H Tanouchi, T Sakai and T Nakashizuka. 1999. Structure, dynamics and disturbance regime of temperate broad- 
leaved forest in Japan. Journal of Vegetation Science 10: 805-814

Mueller-Dombois D and H Ellenberg. 1974. Aims and methods of vegetation ecology. New York: John Wiley and Sons. $547 \mathrm{p}$

Newbery DMcC, E Renshaw and EF Brunig. 1986. Spatial patterns of trees in Kerangas forest Sarawak. Vegetatio 65: 77-89

Odum EP. 1971. Fundamentals of ecology. Philadelphia: W. B. Saunders Company. $574 \mathrm{p}$

Onaindia M, I Dominguez, I Albizu, C Garbisu and I Amezaga. 2004. Vegetation diversity and vertical structure as indicators of forest disturbance. Forest Ecology and Management 195: 341-354

Petraitis PS, RE Lathamm and RA Niesenbau. 1989. The maintenance of species diversity by disturbance. Quarterly Review of Biology 64: 393418

Phillips OL, P Hall, AH Gentry, SA Sawyer and R Vasquez. 1997. Species richness, tropical forest dynamics and sampling; response to Sheil. Oikos 79: 183-190

Ramirez-Marcial N, M Gonzalez-Espinosa and GWilliams-Linera. 2001. Anthropogenic disturbance and tree diversity in Montane Rain Forest in Chipas, Mexico. Forest Ecology and Management 154:311-326

Richards PW. 1996. The tropical rainforest. Cambridge: Cambridge University Press. 575 p

RoderW, G Gratzer and KWangdi. 2002. Cattle grazing in the conifer forests of Bhutan. Mountain Research and Development 22(4): 368-374

Sagar R, AS Ragubanshi and JS Shing. 2003. Trees composition, dispersion and diversity along a disturbance gradient in a dry tropical forest region of India. Forest Ecology and Management 186: 61-71

Shankar U, SD Lama and KS Bawa. 1998. Ecosystem reconstruction through 'taungya' plantations following commercial logging of a dry, mixed deciduous forest in Darjeeling Himalaya. Forest Ecology and Management 102: 131-142

Shannon CE and W Weiner. 1949. The mathematical theory of communication. Urbana: University of Illinois Press, Illinois. $144 \mathrm{p}$

Sheil D. 1999. Tropical forest diversity, environmental change and species augmentation: After intermediate disturbance hypothesis. Journal of Vegetation Science 10: 851-860

Shrestha TB. 1982. Ecology and vegetation of north-west Nepal. Kathmandu: Royal Nepal Academy, Kamaladi. $121 \mathrm{p}$

Simpson EH. 1949. Measurement of diversity. Nature 163: 688

Stainton JDA. 1972. Forests of Nepal. London: John Murray and Company Ltd. $181 \mathrm{p}$

Tachibana T and S Adhikari. 2004. Forest resources condition in Nepal: Effects of management systems and impact on users' welfare. Incomplete draft of a project report. Kobe: Kobe University. Available from author

Vetaas OR. 2000. The effect of environmental factors on the regeneration of Quercus semecarpifolia Sm. in central Himalaya, Nepal. Plant Ecology 146: 137-144

World Bank. 1978. Nepal staff projects reports and appraisal of the community forestry development and training projects. Washington DC: World Bank 